\title{
Identification and Evaluation of Cellular and Biochemical Changes in Responses to Desiccation Tolerance in Cheilanthes Albomarginata Fern
}

\author{
Chaitra $\mathrm{H}^{1}$, Lavanya $\mathrm{PM}^{1}$, Pavitra $\mathrm{K}^{1}$, Sharatchandra $\mathrm{RG}^{1}{ }^{*}$, Yogendra $\mathrm{K}^{2}$ \\ and Yathisha $\mathrm{NS}^{1}$ \\ ${ }^{1}$ Centre for Bioinformation, Department of Studies and Research in Environmental Science. Tumkur University, \\ Tumakuru, India-57210 \\ ${ }^{2}$ Department of Studies and Research in Environmental Science, Kuvempu University, Shankaraghatta, \\ Shimoga, India- 577451 \\ Corresponding Author: Sharatchandra RG
}

\begin{abstract}
Cheilanthes albomarginata (CA) is a fern belongs to Pteridaceae family and is found mainly in hills of India, Pakistan and Nepal at an altitudes 1300-2700m. It grows in rock crevices and has been recognized as a desiccation tolerant (DT) plant. It has the ability to survive under complete desiccation and resurrect under minimal water conditions. An extensive field survey was conducted in Devarayanadurga State Forest, Tumakuru district which led to collection and positive identification of CA. Also, studied desiccation tolerance in the CA. Detached fronds from healthy plants are fully hydrated then subsequent desiccation and rehydration are subjected to experimental study. During desiccation, the relative water content $(R W C)$ of detached desiccated fronds decreased rapidly to $9.2 \%$ after 13 hrs and desiccated fronds showed intense inward curving as a result of water loss. During rehydration, the RWC of the detached fronds regained to $90.68 \%$ within 4 hrs. The rehydrated fronds regained broadly the original morphology. Further, activities of antioxidant enzymes (SOD, $P O D, C A T$, and GR), lipid peroxidation, proline and relative electrolyte leakage increased during desiccation. Also sucrose and starch content showed varying response to desiccation stress. However, plasma membrane integrity was lost during to dehydration. The results obtained revealed that CA is metabolically potent to tolerate desiccation.
\end{abstract}

Keywords: Resurrection plant, desiccation stress, hydration, antioxidants, Cheilanthes albomarginata, $R W C$

\section{Introduction}

Resurrection plants have remarkable ability to survive $95 \%$ dehydration of their vegetative tissue water content and resurrect Upon rehydration they recover their biophysical and chemical functions again, this nature of mechanism occurs only in a few desiccation tolerant resurrection plants. Desiccation tolerance (DT) is defined as the plants ability to completely dry with moderate dry air then resurrect and become functionally active again when rehydrated [1].

Desiccation stress leads to complete disruption of metabolic functions and any plant tolerant to desiccation should be able to maintain its physiological integrity and also regulate its repair mechanism [2,3]. Resurrection plants are considered to be an excellent model to study the mechanisms associated with DT and physiologic responses related extreme drought tolerance.

DT species have been discovered in various ecological niches with perineal water scarcity and unreliable rainfalls; they also inhabit inselberg soils with very low water retention capacity and also outcrops in tropical/subtropical forests. They have been identified in all continents [4]. The majority of DT plants identified now are from the tropics and subtropics of East-West Africa, southern Africa (incl. Madagascar), Brazil, Australia, North America and the Western and Eastern Ghats of India [5]. Biology of the plants indicate that they may have evolved from early land plants [6]. Further, the evolution of more complex vascular plants might have led to DT in reproductive tissues which was lost in vegetative tissues [7]. The mechanisms of DT in lower order resurrection plants like, algae, lichens and bryophytes are different from angiosperm DT plants [8,9].

The genus Cheilanthes is tropical in nature and is traditionally used to treat peptic ulcer and stomach disorders. These plants are also found in desiccated state and resurrect when water is available. In lower plants, desiccation tolerance occurs in terrestrial microalgae, bryophytes [6] and lichens [10,11], but rarely in Pteridaceae $[12,1]$. 
Water stress is a limiting environmental factor that reduces the yield and growth of a plant. Majority of plants are sensitive to water deficit, losing physiological capacity upon water loss of between 41 and $70 \%$. The desiccation sensitive plants undergo stress leading to multiple damage and loss of protein conformation [13]. Chromatin stability and oxidative damage occurs extensively [14]. Further, some DT plants around in specialized niches by adapting to faster growth and high dry mass productivity along with other physical mechanisms like water-related adaptations like formation of stomata, cuticle and modifications in the root of the vascular system $[1,6,7,15]$. Some Cheilanthes species have been reported to survive the loss of up to $95 \%$ of total cellular water content, for prolonged periods of time. And which recover full metabolic activity in existing tissues within $12-72 \mathrm{~h}$ of rehydration. Although it is well documented that there are several species of Pteridaceae with vegetative DT for example [16].

\subsection{Identification of Cheilanthes Albomarginata}

\section{Materials and Methods}

Cheilanthes albomarginata were identified based on the fallowing morphological features

a. Length of stipes

b. Morphology, colour and size of the leaves

c. Types of scales and fronds

We collected Cheilanthes sp. That grows naturally on rocks in Devarayanadurga Stare forest of Tumakuru District of Coordinates $13.3707^{\circ} \mathrm{N}, 77.1773^{\circ} \mathrm{E}$. In this study we have collected and identified Cheilanthes albomarginata from Devarayanadurga forest region of Tumakuru district during July (monsoon) and November (non-monsoon) months.

\subsection{Relative Water Content Analysis}

We selected the plants of homogeneous age, their aerial parts are similar in size and belonged to the same habitat they were maintained in pots under a greenhouse condition favorable for healthy plant growth, with regular irrigation for 30 days prior to in vitro desiccation stress treatment. From the healthy and young $C A$ plants, detached fronds were immediately allowed to hydrate in a petri dish (150mm X 20mm Size) fallowed with double distilled water, until it did not further weight gain or the increased weight reached saturation such type of plant tissue were considered as hydrated fronds (HF), The HF tissues were allowed to desiccate in room temperature until no further weight loss occurred and the loss of weight reached saturation such tissues were considered as desiccated fronds (DF). The DF tissues were further rehydrated in a petri dish with double distilled water until no further weight gain took place under similar light or dark cycle, these plant tissue were considered as rehydrated fronds (RF). The dry weight of RF tissues were obtained by baking at $105^{\circ} \mathrm{C}$ for 15 min, then subsequent drying at $80^{\circ} \mathrm{C}$ until the weight stabilized that. We treated all plant material required for further analysis in the same way. Then HF, DF and RF tissues were grinded using liquid nitrogen and stored in $80^{\circ} \mathrm{C}$ for the further analysis. The water content in the samples was calculated as the difference between fresh weight and dry weight divided by the fresh weight [17]. RWC is expressed in percentage.

\subsection{Chlorophyll and Carotenoid Measurements}

$0.5 \mathrm{~g}$ of CA leaf HF, DF and RF tissues was frozen using liquid nitrogen and homogenised using mortar and pestle. From the homogenised samples chlorophyll was extracted with $10 \mathrm{~mL} 80 \%$ acetone. The test tubes were wrapped with aluminium foil and left in room temperature overnight, then crude extract was centrifuged at $3000 \mathrm{~g}$ for $5 \mathrm{~min}$ using Centrifuge 5400R (Eppendorf CA USA) and the supernatant was collected while the pellet was discarded. The absorbance of the supernatant was read at $663.6 \mathrm{~nm}, 646.6 \mathrm{~nm}$ and $440.5 \mathrm{~nm}$ by using BioSpectrometer Kinetic (Eppendrof CA USA), which are the major absorption peaks of chlorophylls $a, b$, and carotenoids, respectively [18]. The total chlorophyll $(C h l a+b)$ and total carotenoid (Car) contents were calculated using extinction coefficients provided by Porra et al [18]. The chlorophyll and carotenoid concentrations were then expressed on the basis of $\mu \mathrm{g} \mathrm{chl} / \mathrm{g}$ dry sample $(\mu \mathrm{g} g-1)$.

\subsection{Estimation of Lipid Peroxidation}

Lipid peroxidation in fronds of all the HF, DF and RF were determined as 2-thiobarbituric acid (TBA) reactive metabolites chiefly malondialdehyde (MDA) as described by $[19,20] .0 .2 \mathrm{~g}$ of the tissues were extracted in $2 \mathrm{ml}$ of $0.25 \%$ TBA made in $10 \%$ TCA. Extract was heated at $95^{\circ} \mathrm{c}$ for 30 minutes then quickly cooled, further the samples were centrifuged at $10000 \mathrm{~g}$ for 10 minutes, then the absorbance of the supernatant was read at $532 \mathrm{~nm}$ and $600 \mathrm{~nm}$, by subtracting the absorbance value taken at $600 \mathrm{~nm}$, correction of non-specific turbidity was carried out. The lipid peroxidation levels were expressed in $\mathrm{n} \mathrm{mol} \mathrm{g}{ }^{-1} \mathrm{FW}$ of MDA made using an extinction coefficient of $155 \mathrm{mM} \mathrm{cm}^{-1}$. 
Identification and Evaluation of Cellular and Biochemical Changes In Responses to Desiccation ..

\subsection{Proline Estimation}

Free proline accumulation of $C A$ in HF, DF and RF was determined using the method of [20,21] 0.04 $\mathrm{g}$ of $C A$ leaves were homogenized with $3 \%$ sulfosalicylic acid and after 72 hours proline released was measured. The homogenate was centrifuged at $3000 \mathrm{~g}$ for 20 minutes. The supernatant was treated with acetic acid ninhydrin, boiled for 1 hour and then absorbance at $520 \mathrm{~nm}$ was determined. Contents of proline were expressed as $\mathrm{mg} \mathrm{g}^{-1} \mathrm{dw}^{-1}$.

\subsection{Analysis of Antioxidant Enzymes}

Activities of four antioxidant enzymes (SOD, CAT, POD, and GR) were determined in HF, DF and RF. Tissues were grounded separately in $6 \mathrm{~mL}$ of extraction buffer-1 (50 mM PBS, pH 7.8 for SOD and CAT assays) and $6 \mathrm{~mL}$ extraction buffer-2 (100 mM PBS, pH 7.0 for POD and GR assays) at $4{ }^{\circ} \mathrm{C}$. The homogenates were collected and centrifuged at $15000 \mathrm{~g}$ at $4{ }^{\circ} \mathrm{C}$ for $20 \mathrm{~min}$. SOD was assayed on the basis of its ability to inhibit the photochemical reduction of nitro blue tetrazolium (NBT). A $6 \mathrm{~mL}$ reaction solution of SOD consisted of $50 \mathrm{mM}$ PBS ( $\mathrm{pH} 7.8$ ), $130 \mathrm{mM}$ methionine, $750 \mu \mathrm{M}$ nitro blue tetrazolium chloride (NBT), $100 \mu \mathrm{M}$ EDTA$\mathrm{Na}^{2+}, 20 \mu \mathrm{M}$ riboflavin, and $0.1 \mathrm{~mL}$ of enzyme extract. The reaction solution was incubated for $10 \mathrm{~min}$ under fluorescent light with an intensity of $50 \mu \mathrm{mol} \mathrm{m}{ }^{2} \mathrm{~s}^{-1}$ for $20 \mathrm{~min}$. The absorbance was determined at $560 \mathrm{~nm}$. One unit of SOD activity was defined as the amount of enzyme required to inhibit photochemical reduction of NBT by $50 \%$ and expressed in Units $\mathrm{mg}^{-1}$ protein. CAT activity was assayed by measuring the initial rate of disappearance of $\mathrm{H}_{2} \mathrm{O}_{2}$ by the technique described by [22]. The decline in $\mathrm{A} 240$ was recorded by BioSpectrometer, and the activity was expressed as the number of $\mu$ mol of $\mathrm{H}_{2} \mathrm{O}_{2}$ catalyzed by a unit of CAT per min and were expressed in units/mg protein. POD activity was analyzed using a modified method of Rao et al [23]. The reaction solution contained $100 \mathrm{mM}$ PBS ( $\mathrm{pH} 7.0$ ), $50 \mathrm{mM}$ o-methoxyphenol, $40 \mathrm{mM} \mathrm{H}_{2} \mathrm{O}_{2}$, and 0.1 $\mathrm{mL}$ of enzyme extract and were expressed in $\mu \mathrm{mol} \mathrm{min}^{-1} \mathrm{~g}^{-1}$ protein. GR activity was determined according to the method described by [24]. The reaction solution consisted of $50 \mathrm{mM}$ Tris-HCl, $0.5 \mathrm{mM}$ GSSG, $5 \mathrm{mM}$ $\mathrm{MgCl}_{2}$, and $0.2 \mathrm{mM} \mathrm{NADPH}$. GR activity was determined at $340 \mathrm{~nm}$, within $3 \mathrm{~min}$ and expressed as the number of $\mu \mathrm{mol}$ of NADPH oxidization and were expressed in Units $\mathrm{mg}^{-1}$ protein.

\subsection{Determination of Soluble Sugar and Starch}

From the frozen frond material of $\mathrm{HF}, \mathrm{DF}, \mathrm{RF}$ tissues of $\mathrm{CA}$ was ground in a mortar with ice-cold $1 \mathrm{M}$ perchloric Acid $\left(\mathrm{HClO}_{4}\right)$, then the extract was centrifuged at $12000 \mathrm{~g}$ for 2 min at $4-8^{\circ} \mathrm{C}$. The supernatant was neutralized with $5 \mathrm{M}$ Potassium carbonate $\left(\mathrm{K}_{2} \mathrm{CO} 3\right)$ and precipitated potassium perchlorate $\left(\mathrm{KClO}_{4}\right)$ was removed by centrifugation. The supernatant was kept on ice and used for the estimation of sucrose, while the pellet was used for the determination of starch. Sucrose and starch were estimated enzymatically according to the Jones method as given by Coombs et al. [25]. Sucrose and starch content were expressed as $\mu \mathrm{mol} / \mathrm{G} \mathrm{FW}$.

\subsection{Measurement of Membrane Permeability}

Membrane integrity of leaf tissues was determined by measuring relative electrolyte leakage (REL). $\mathrm{HF}$, DF and RF tissues $(0.5 \mathrm{~g})$ were rinsed three times with double distilled water. The tissues were cut and completely immersed in $20 \mathrm{~mL}$ of double distilled water, then degassed for $20 \mathrm{~min}$. The electrical conductivity of the solution (E1) was determined using a conductivity instrument SKU-5501 (Countron India). The sample tubes were subsequently incubated in boiling water $\left(100{ }^{\circ} \mathrm{C}\right)$ for $10 \mathrm{~min}$ and allowed to cool to ambient temperature, and then the electrical conductivity of the solution (E2) was measured. In addition, the electrical conductivity of Milli-Q water (E3) was also measured. The REL was calculated using the equation: REL (\%) $(\mathrm{E} 1-\mathrm{E} 3) /(\mathrm{E} 2-\mathrm{E} 3) \times 100 \%[26]$.

\subsection{Quantification of Superoxide Radical $\left(\mathrm{O}_{2 .}\right)$}

Super oxide was analysed according to Fontana et al [27]. $1 \mathrm{~g}$ fronds of HF, DF and RF states of CA were extracted with $100 \mathrm{mM}$ potassium phosphate buffer $\mathrm{pH} 7.2(2 \mathrm{ml})$. To the reaction mixture $500 \mu \mathrm{lof} 2 \mathrm{mM}$ nitro blue tetrazolium (NBT) was added and the incubation was continued for 20 more min. the reaction was stopped by the addition of $2 \mathrm{ml} 1.4$-dioxan. The tubes were placed in water bath at $70^{\circ} \mathrm{C}$ for 15 minutes, cooled, centrifuged at 2000rpm using for 10 minutes to allow the cells to settle and the absorbance of the supernatant was measured at $540 \mathrm{~nm}$. Quantity of super oxide radical was expressed in $\mu \mathrm{mol} / \mathrm{g} \mathrm{FW}$.

\subsection{Statistical Analysis}

Data obtained were subjected to a one-way analysis of variance (ANOVA). Significant differences among the test groups $(P \leq 0.05)$ obtained by Tukey's honestly significant difference (HSD) post hoc test using SPSS software (SPSS20.0,SPSSInc., USA) are depicted in the Figures by various letters. Values shown in the Figures are the means \pm standard errors (SEs) of three independent replicates. 


\section{Results And Discussion}

3.1 Cheilanthes Albomarginata Morphological Identification

Cheilanthes albomarginata was identified based on the fallowing morphological features. These species are green small structural perineal and looks like an ornamental plants. CA belonging to the family Pteridaceae. Rhizome of CA bears tufts of hair and pointed scales. Stipes grow up to $25 \mathrm{~cm}$ long. The leaves were glabrous, reddish brown, shiny, and furnished particularly below when young. It has lanceolate white margined scales. Fronds were bipinnatisect to bipinnate, deltoid to deltoid lanceolate covered with white waxy powder. CA is a type of farinose fern as it contains white or yellow coating on the lower surface of the leaf [28].

\subsection{Relative Water Content}

RWC of CA was estimated in three independent experiments using detached fronds of CA plants such as HF, DF and RF under laboratory conditions and at each stages photos of a fronds were captured using a digital camera (Nikon D3300 Digital SLR Camera). During desiccation the RWC content decreased to $9.20 \%$ after 12 hours. During the rehydration the fronds regained its weight and RWC to $90.68 \%$, the percentage of recovery shows that a key characteristics of desiccation tolerant plants. Hence RWC is the technique for appropriate measure of plant water balance status in terms of cellular water deficit associated with physiological consequences.

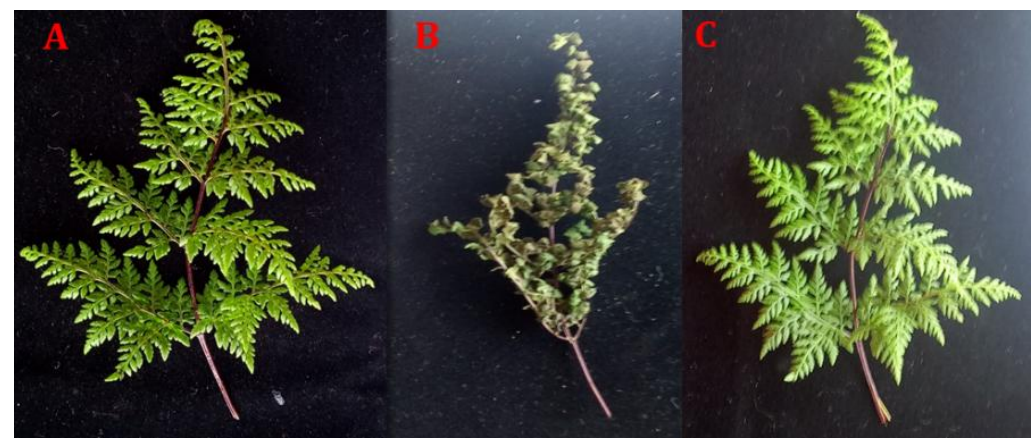

Figure 01 Cheilanthes albomarginata morphological changes of detached fronds in a. Hydrated frond serves as control (HF, RWC 90.80\%). b. desiccated frond (DF, RWC 9.20\%). c. and rehydrated (RF, RWC 90.68\%).

\subsection{Pigment Content}

Illustrated in Figure 02 is the total chlorophyll content $(C h l a+b)$ in HF, DF and RF of CA plant. We observed that there were significant difference in the $\mathrm{Chl} a+b$ among hydrated, desiccated and rehydrated states. The Chl $a+b$ in DF dropped to $39.97 \mu \mathrm{g}$ g-1 from $50.23 \mu \mathrm{g}$ g-1 which shows that approximately $80 \%$ of the total chlorophyll of the HF was retained during the desiccation. However, during rehydration chlorophyll content was found to be $47.94 \mu \mathrm{g}$ g-1 which was percentage of that of HF. This indicates that chloroplasts recovered and became functional during rehydration. Further CA species are shown a mechanism of protecting chlorophyll content from total destruction during desiccation.

Decrease in chlorophyll content of leaves is thought to be linked to the protection of plants against UV light and from damage as a result of oxygen free radical generation during desiccation [29]. Similarly chlorophyll content of the leaves did not drop too much in desiccated CA indicating that no complete dismantling of photosynthetic apparatus was observed. Also, CA did not lose all its chlorophyll because the plant itself is protected from irradiation damage through different mechanisms. It is also observed that heavy in curling takes place during desiccation which helps in the functional leaves being protected. The adaxial side of the leaves remained green while the abaxial side did not. It must be noted, however, that the total chlorophyll in DF was only $20 \%$ lesser in desiccation state, indicating that destruction did not affect the photosynthesis.

Desiccation-tolerant plants can be classified based on how they retain their photosynthetic pigments during desiccation or not, Oliver et al [1], stated that desiccation-tolerant plants that retain their chlorophyll content during dry state are homoichlorophyllous while those that dismantle their chlorophyll are termed poikilochlorophyllous. On this basis, Farrant [30] classified the resurrection angiosperms C. wilmsii and Myrothamnus flabellifolius as homoichlorophyllous species because they retained some of their chlorophyll content, $82 \%$ and $60 \%$ chlorophyll, respectively. Since $C A$ retained $80 \%$ of its chlorophyll in the dehydrated state, it can be classified then as homoichlorophyllous species. Upon rehydration, this partial loss of chlorophyll was regained more or less o the original levels. It appears that $C A$ is desiccation tolerant based on the observations we have made on protection of chlorophyll during desiccation. Additionally, non-irrigation of $C A$ also prolonged its normal hydrated state to 30 days. The plants remained as they were visually during the period even at $10 \%$ RWC and did not bleach at all. Moreover, $C A$ curved and folded its rosette shoot upward during 
drying which aided to protect its adaxial surface and safeguard the inner rosette shoot. A similar morphological strategy has also been observed in $C$. wilmsii, C. plantagineum, and M. flabellifolius [30,31]. This strategy would stop photochemical degradation of chlorophyll as the functional leaves are covered by the outer or aged leaves [30].

\subsection{Proline Accumulation}

Proline levels in HF, DF and RF fronds of CA were expressed in terms of $\mu \mathrm{mol} / \mathrm{g} \mathrm{FW}$. It was clearly evident that the proline levels increased rapidly during DF. In hydrated stage it was found to be $0.495 \mu \mathrm{mol} / \mathrm{g}$ FW and desiccated stage proline content increased to $1.545 \mu \mathrm{mol} / \mathrm{g} \mathrm{FW}$. During rehydration it was found to be $0.247 \mu \mathrm{mol} / \mathrm{g} \mathrm{FW}$, these results showed that a drastic increase in the proline concentration during desiccation which probably indicate a role in DT. Accumulation of amino acids has been observed in many studies on plants exposed to desiccation stress [32]. Proline is considered to act as an osmolyte, a ROS scavenger, and a molecular chaperone stabilizing the structure of proteins, thereby protecting cells from damage caused by stress [33].

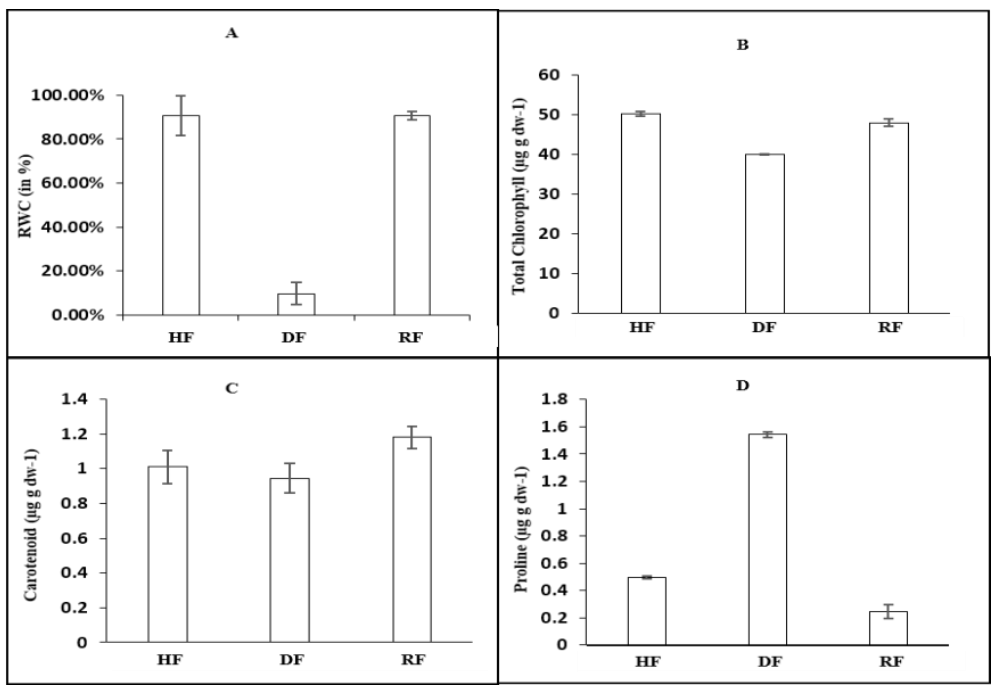

Figure 02 Cheilanthes albomarginata resurrection plant is subjected to stress treatments. Fallowing hydrated (HF) plants were subjected to desiccation (DF) and subsequent rehydration (RF). (A) Relative water content (RWC in Gms). (B) Total chlorophyll $(C h l a+b)$ contents. (C) Total carotenoid contents. (D) Proline levels. Error bars represent standard error within the test group $(p \leq 0.05)$, obtained from three replicates.

\subsection{Activity of Antioxidant Enzymes}

We analysed the activities of four antioxidant enzymes superoxide dismutase (SOD), peroxidase (POD), catalase (CAT) and glutathione reductase (GR), to evaluate the effect of desiccation on plant antioxidation system. The activities of all four enzymes increased gradually and consistently during desiccation and returned to approximately original levels during rehydration. SOD activities increased from $0.264 \mathrm{Units}^{-\mathrm{mg}^{-}}$ ${ }^{1}$ protein in HF to 0.506 Units $\mathrm{mg}^{-1}$ protein in DF and in RF it was found to be $0.372 \mathrm{Units} \mathrm{mg}^{-1}$ protein. The peroxidase (POD) concentration in CA in HF was $551.7 \mu \mathrm{mol} \mathrm{min} \mathrm{m}^{-1} \mathrm{~g}^{-1}$ protein which increased in DF to about $625 \mu \mathrm{mol} \mathrm{min} \mathrm{m}^{-1} \mathrm{~g}^{-1}$ protein. Thereafter, it decreased in RF to about $419 \mu \mathrm{mol} \mathrm{min}^{-1} \mathrm{~g}^{-1}$ protein. GR activities of CA were found to be $0.563 \mathrm{Units} \mathrm{mg}^{-1}$ protein, in HF its which increased to $1.527 \mathrm{Units}_{\mathrm{mg}}{ }^{-1} \mathrm{protein}$ in DF and decreased marginally to 0.926 Units $\mathrm{mg}^{-1}$ protein in RF. CAT activities in CA increased in DF and fallowed the same trend like other antioxidant enzymes. In HF it was found to be 64 units/mg protein which increased to 94.7 units/mg protein in DF and in RF it was at 45 units $/ \mathrm{mg}$ protein. These results indicated that anti-oxidation mechanisms have been triggered and support the hypothesis that the desiccation damage to the plants was mainly caused by oxidative stress, in terms of ROS accumulation. Plant oxidative stress is a complex physiological phenomenon. It develops as a result of overproduction of reactive oxygen species (ROS). ROS that includes the singlet oxygen $\left({ }^{1} \mathrm{O}_{2}\right)$, superoxide $\left(\mathrm{O}_{2}-\right)$, hydrogen peroxide $\left(\mathrm{H}_{2} \mathrm{O}_{2}\right)$ and hydroxyl radical $(\mathrm{HO})$. The generation of ROS in plants is triggered by desiccation. To eliminate excessive oxidative stress, antioxidant mechanism are active during stressful conditions. 


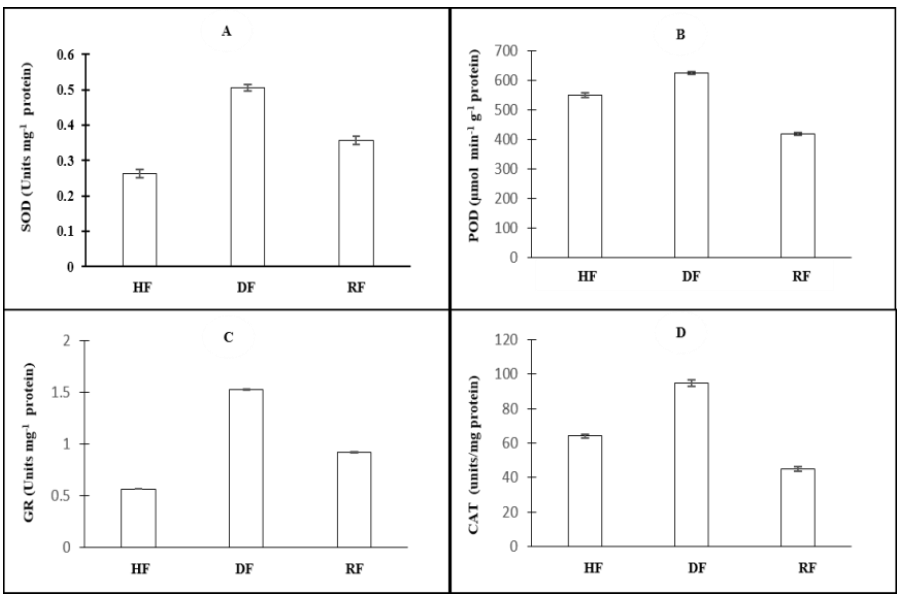

Figure 03 Specific activity of (A) Superoxide dismutase (B) Peroxidase (C) Glutathione reductase (D) Catalase in HF, DF and RF tissues of Cheilanthes albomarginata. All antioxidant enzymes increased in DF compare to $\mathrm{HF}$ and little minimized in RF. It indicates that during the desiccation stress antioxidants are overexpressed to eliminate the oxidative stress. Error bars represent standard error within the test group $(p \leq 0.05)$, obtained from three replicates.

\subsection{Lipid Peroxidation}

The main cellular components susceptible to damage by free radicals are lipids (peroxidation of unsaturated fatty acids in membranes), lipid peroxidation indicates the oxidative stress in response to desiccation which will result in damage to membranes and inactivation of enzymes, i.e., resulting in loss of cell viability $[34,35]$. Lipid peroxidation in CA was estimated as reactive metabolites of 2-TBA mainly MDA. In HF it is found to be $0.457 \mathrm{n}$ mol g- $1 \mathrm{FW}$. In DF tissues MDA was found to be $0.662 \mathrm{n} \mathrm{mol} \mathrm{g-1} \mathrm{FW,} \mathrm{further} \mathrm{it}$ reduced to $0.417 \mathrm{n}$ mol g-1 FW in RF of CA.

\subsection{Membrane Permeability}

To determine the levels of membrane integrity and permeability of the cell membrane in CA relative electrolyte leakage (REL) was measured at all stages. In the HF it was at $10 \%$, in desiccation state it was $21 \%$ and in rehydrated state it was 17\%. Significant increase in REL level during desiccation indicated that DF of CA loss their membrane integrity hence electrolyte inside of cells was come out to some extents, and in RF of CA membrane permeability is little lower then HF it implies regain of membrane integrity.

\subsection{Superoxide Radical}

Superoxide concentrations were expressed as $\mathrm{n} \mathrm{mol} / \mathrm{gm}$ fresh weight and were quantified in HF, DF and RF tissues of CA. Increase in superoxide concentration was evident during the desiccation phase as it increased from be 0.23 to $0.68 \mathrm{n} \mathrm{mol} / \mathrm{gm}$. During the rehydration state it was found to be $0.25 \mathrm{n} \mathrm{mol} / \mathrm{gm} \mathrm{FW}$. Increased rate of superoxide radical level in DF of CA suggesting that oxidative stress was occurred due to desiccation stress.

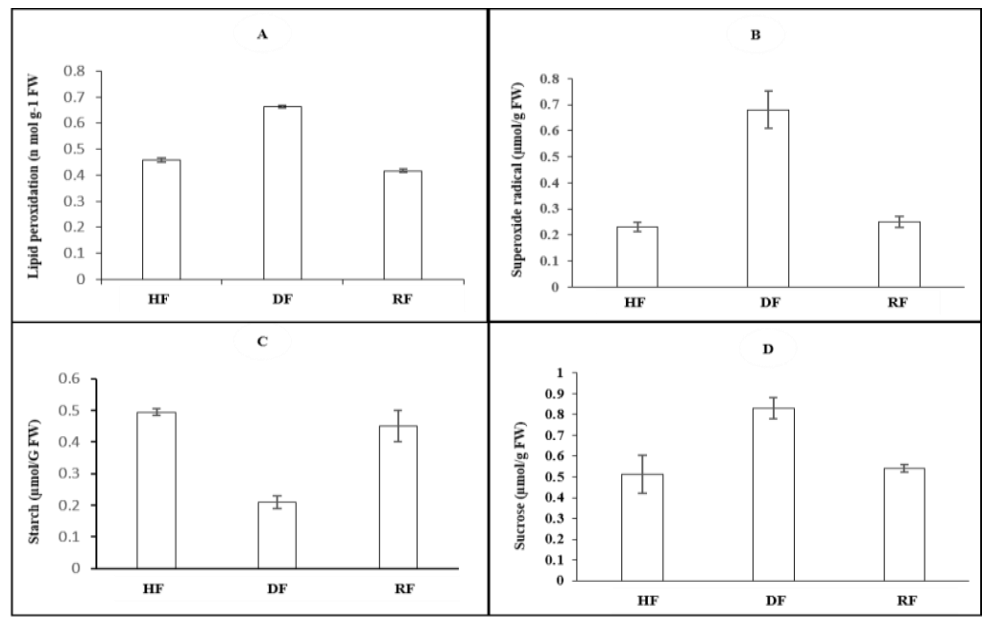

Figure 04 Changes in the levels of (A) Lipid peroxidation (MDA), (B) Superoxide Radical $\left(\mathrm{O}_{2-}\right)$, (C) Starch, (D) Sucrose in HF, DF and RF tissues of Cheilanthes albomarginata. Error bars represent standard error within the test group $(p \leq 0.05)$ obtained from three replicates. 


\subsection{Soluble Starch and Sugars}

Sucrose content was expressed as $\mu \mathrm{mol} / \mathrm{g} \mathrm{FW}$ and it showed a decrease in the desiccated and rehydrated fronds. Sucrose content in HF, DF and RF fronds was found to be $0.895,0.337$ and $0.542 \mu \mathrm{mol} / \mathrm{g}$ FW respectively. The starch concentration was to be found HF is $0.522,1.132$ and $0.664 \mu \mathrm{mol} / \mathrm{g} \mathrm{FW}$ in HF, DF and RF respectively. In this study Starch content decreases and sucrose content was increases in DF of CA, previous studies are evident that starch is a carbohydrate storage in DT plants and it is degraded during desiccation, starch provide carbon resource for sucrose. Higher amount of sucrose in DF of CA suggests that it's a positive effector of proline accumulation. We observed concentrations of soluble sugars increased at the same time decrease in starch concentration was also observed. It implies that increased fraction was go together with by a decrees in starch fraction in DF of CA. Sugars protects the cells during desiccation by maintaining hydrophilic interactions in proteins and membranes by substituting water from Hydroxyl groups of sugars. Hence, through hydrogen -bonding sugars interact with proteins and membrane, by this way prevent denaturation of protein. Sugars are considered are a key contributing factor to vitrification. Thus, in the cytoplasm of desiccated cells biological gas is formed.

\section{Conclusion}

In this study results obtained demonstrate that the Cheilanthes albomarginata plant is able to survive desiccation stress ant is able to resurrect later we hypothesis that like Cheilanthes albomarginata plant is able to survive desiccation due to increase in proline, Superoxide Radical and antioxidants such as SOD, POD, CAT and GR. However, membrane permeability was lost during desiccation indicates REL. Further, the sucrose content was maximum while starch content is minimum in desiccated fronds due to increase in water loss. These results indicates that the desiccation tolerance in Cheilanthes albomarginata accompanied by a robust and physiological and biochemical responses. DT in CA expressed among all the tissues unlike higher plants were DT is tissue specific the reason for DT in the whole tissues might be due to a combination of morphological change. Osmolyte and antioxidant accumulation and protecting photosynthetic apparatus during desiccation.

\section{Acknowledgement}

Authors thank IFCPRA and SERB for funding support.

\section{References}

[1] Alpert P (2005) Sharing the secrets of life without water. Integrative and Computation Biology 45:683-684.

[2] Levitt J (1980) Responses of Plants to Environmental Stresses. Water, Radiation, Salt and Other Stresses. Academic Press, New York. 2:365.

[3] Bohnert HJ, Nelson DJ, Jensen RG (1995) Adaptations to environmental stresses. Plant Cell 7:1099-1111.

[4] Porembski S, Barthlott W (2001) Granitic and gneissic outcrops (inselbergs) as centres of diversity for desiccation tolerant vascular plants. Plant Ecology 151:19-28.

[5] Kappen L, Valladares F (1999) Opportunistic growth and desiccation tolerance: the ecological success of poikilohydrous autotrophs. In: Pugnaire F. I. \& Valladares F. (eds), Handbook of functional plant ecology. Marcel Dekker, New York, 9-80

[6] Oliver MJ, Velten J, Mishler BD (2005) Desiccation tolerance in bryophytes; a reflection of the primitive strategy for plant survival in dehydrating habitats? Integrative and Computation Biology 45: 788-799.

[7] Oliver M J, Tuba Z and Mishler B D (2000) The evolution of vegetative desiccation tolerance in land plants. Plant Ecology 151: 85-100.

[8] Oliver MJ, Bewley JD (1997) Desiccation tolerance of plant tissues: a mechanistic overview, Horticultural Reviews 18:171-214

[9] Oliver MJ, Wood AJ, O’Mahony P (1998) To dryness and beyond preparation for the dried state and rehydration in vegetative desiccation tolerant plants. Plant Growth Regulation 24:193-201.

[10] Candotto CF, Zanelli D, Bertuzzi S, Tretiach M (2015) Desiccation tolerance and lichenization: a case study with the aeroterrestrial microalga Trebouxia sp (Chlorophyta). Planta. Doi:10.1007/s00425-015-2319-z.

[11] Kranner I, Beckett R, Hochman A, Nash TH (2008) Desiccation tolerance in lichens: A Review. Bryologist 11, $576-593$. doi:10.1639/0007-2745-111.4.576.

[12] Bewley JD (1979) Physiological aspects of desiccation tolerance. Annual Review of Plant Physiology 30:195-238

[13] Tapia H, Koshland DE (2014) Trehalose is a versatile and long-lived chaperone for desiccation tolerance. Current Biology 24:27582766.

[14] Dinakar C, Bartels D (2012) Light response, oxidative stress management and nucleic acid stability in closely related Linderniaceae species differing in desiccation tolerance. Planta 236:514-555. Oliver M J, Tuba Z and Mishler B D (2000) The evolution of vegetative desiccation tolerance in land plants. Plant Ecology 151:85-100.

[15] Illing N, Denby KJ, Collett H, Shen A, Farrant JM (2005) The signature of seeds in resurrection plants: a molecular and physiological comparison of desiccation tolerance in seeds and vegetative tissues. Integrative and Computation Biology 45:771-787.

[16] Alpert P, Oliver MJ (2002) Drying without dying. In M. Black and H. W. Prichard (eds.), Desiccation and survival in plants: Drying without dying, CAB International, Wallingford, UK. pp. 3-43.

[17] Richard ES, Gail EB (1974) Rapid Estimates of Relative Water Content. Plant Physiology. 53, 258-260.

[18] Porra R J, Thompson W A and Kriedemann P E. (1989). Determination of accurate extinction coefficients and simultaneous equations for assaying chlorophylls $a$ and $b$ extracted with four different solvents: Verification of the concentration of chlorophyll standards by atomic absorption spectroscopy. Biochimica et Biophysica Acta (BBA)-Bioenergetics 975: 384-394.

[19] Heath RL, Packer L (1968) Photoperoxidation in isolated chloroplasts. I. Kinetics and stoichiometry of fatty acid peroxidation. Archiver Biochemistry Biophysics 125:189-90.

[20] Li, H. S.; Sun, Q.; Zhao, S. J.; Zhang, W. H., Ed. In Principles and Techniques of Plant Physiological Biochemical Exp. Higher Education Press: Beijing, 2000. 
[21] Bates LS, Waldren RP, Teare ID (1973) Rapid determination of free proline for water stress studies. Plant Soil 39:205-7.

[22] Change B, Maehly AC (1995) Assay of catalases and peroxidase. Meth Enzymol 2:764-775.

[23] Rao MV, Hale BA, Ormro DP (1995) Amelioration of ozone induced oxidative damage in wheat plants grown under high carbon dioxide. Plant Physiology 109:421-432.

[24] Halliwell B, Foyer CH (1978) Properties and physiological function of a glutathione reductase purified from spinach leaves by affinity chromatography. Planta 139:9-17.

[25] Coombs J, Hind G, Leegood RC, Tieszen LL, Vonshak A. Analytical techniques. In: Coombs J, Hall DO, Long SP, Scurlock JM, editors. Techniques in bioproductivity and photosynthesis. Oxford: Pergamon Press 1985. pp. 219-228.

[26] Shi H, Wang Y, Cheng Z, Ye T, Chan Z (2012). Analysis of natural variation in bermudagrass (Cynodon dactylon) reveals physiological responses underlying drought tolerance. PLoS ONE7:e53422. 10.1371/journal.pone.0053422

[27] Fontana M, Mosca L, Rosei MA (2001) "Interaction of enkephalins with oxyradicals," Biochemical Pharmacology 61. 1253-1257.

[28] Wollenweber E, Schneider H (2000) Lipophilic exudates of Pteridaceae-chemistry and chemotaxonomy. Biochemical Systematics and Ecology 28:751-777.

[29] Sherwin HW, Farrant JM (1998) Protection mechanisms against excess light in the resurrection plants Craterostigma wilmsii and Xerophyta viscosa. Plant Growth Regulation 24:203-210.

[30] Farrant JM (2000) A comparison of mechanisms of desiccation tolerance among three angiosperm resurrection plant species. Plant Ecology 151:29-39

[31] Scott P (2000) Resurrection plants and the secrets of eternal leaf. Annals of Botany 85:159-166.

[32] Widodo JH, Patterson EN, Mark T, et al. (2009) Metabolic responses to salt stress of barley (Hordeum vulgare L.) cultivars, Sahara and Clipper, which differ in salinity tolerance. Journal of Experimental Botany 60:4089-4103.

[33] Bhaskara GB, Yang TH, Verslues PE (2015) Dynamic proline metabolism: importance and regulation in water limited environments. Frontiers in Plant Science: 484.

[34] Mittler R (2002) Oxidative stress, antioxidants and stress tolerance. Trends in Plant Science 7:405-410.

[35] Mattos LM, Moretti CL (2015) Oxidative Stress in Plants under Drought Conditions and the Role of Different Enzymes. Enzyme Engineering 5:136.

IOSR Journal of Biotechnology and Biochemistry (IOSR-JBB) is UGC approved Journal with S1. No. 4033, Journal no. 44202.

L- - - - - - - - - - - - - - - - - - - - - - - - - - - - - - - - - - - - - - - - - - - - - -

Chaitra H. "Identification and Evaluation of Cellular and Biochemical Changes In Responses to Desiccation Tolerance in Cheilanthes Albomarginata Fern." IOSR Journal of Biotechnology and Biochemistry (IOSR-JBB) 3.4 (2017): 25-32. 